\title{
Methylmercury toxic mechanism related to protein degradation and chemokine transcription
}

\author{
Jin-Yong Lee ${ }^{1 *}$, Gi-Wook Hwang ${ }^{2,3}$, Akira Naganuma ${ }^{3}$ and Masahiko Satoh ${ }^{1}$
}

\begin{abstract}
Methylmercury is an environmental pollutant that causes neurotoxicity. Recent studies have reported that the ubiquitin-proteasome system is involved in defense against methylmercury toxicity through the degradation of proteins synthesizing the pyruvate. Mitochondrial accumulation of pyruvate can enhance methylmercury toxicity. In addition, methylmercury exposure induces several immune-related chemokines, specifically in the brain, and may cause neurotoxicity. This summary highlights several molecular mechanisms of methylmercury-induced neurotoxicity.
\end{abstract}

Keywords: Methylmercury, Ubiquitin-proteasome pathway, Pyruvate, Mitochondria, Chemokines

\section{Introduction}

Methylmercury is a toxic metal that causes severe central nervous system disorders such as Minamata disease [1] and is produced by the biomethylation of inorganic mercury by microorganisms [2]. Methylmercury enters the aquatic food chain and accumulates in carnivorous fish [2,3]. Levels of methylmercury in seawater have been estimated at $10.7-$ $99.1 \mathrm{pg} / \mathrm{L}$ and those in swordfish at $249-1187 \mu \mathrm{g} / \mathrm{kg}$ [3]. The biomethylation and bioaccumulation of methylmercury result in human exposure through consumption of fish, and high intake can exert health risks, especially to the developing fetus $[4,5]$.

More than $90 \%$ of ingested methylmercury is absorbed from the gastrointestinal tract [4], and approximately $10 \%$ reaches the brain $[4,6]$. Methylmercury can also cross the placental barrier, and methylmercury levels in the fetal brain can reach 5-7 times higher than those in maternal blood [7], which indicates the high health risk to the fetus. The main adverse effect of methylmercury exposure is neurotoxicity [8], and the clinical manifestation

\footnotetext{
* Correspondence: leejy@dpc.agu.ac.jp

${ }^{1}$ Laboratory of Pharmaceutical Health Sciences, School of Pharmacy, Aichi Gakuin University, 1-100 Kusumoto-cho, Chikusa-ku, Nagoya 464-8650, Japan Full list of author information is available at the end of the article
}

of methylmercury poisoning includes paresthesia, ataxia, vision and hearing loss, tremors, and spasticity $[9,10]$.

The human pharmacokinetics and pharmacodynamics of methylmercury have been elucidated, and several molecular events, such as the generation of reactive oxygen species and disruption of calcium homeostasis, can be induced by methylmercury $[11,12]$. Several intracellular pathways of methylmercury toxicity have been identified; this brief review discusses for the current understanding of the molecular mechanisms related to methylmercuryinduced neurotoxicity.

\section{The ubiquitin-proteasome system and mitochondrial function}

Budding yeast (Saccharomyces cerevisiae) is a unicellular eukaryote, and many of its gene products have similar functions to those of mammals [13]. CDC34 has been identified as a gene that confers resistance to methylmercury in yeast cells $[14,15]$. CDC34 encodes the Cdc34 protein, a ubiquitin-conjugating enzyme, which is involved in the ubiquitin-proteasome protein degradation system [16]. Overexpression of Cdc34 in human cells has been shown to result in significant resistance to methylmercury [15], and this protective effect is suppressed 
by the inhibition of proteasome activity [15]. These findings suggest that methylmercury induces cellular accumulation of certain proteins and that this accumulation is toxic; further, these proteins are degraded via the ubiquitinproteasome system.

Cdc34 is an E2 enzyme of the ubiquitin-proteasome system and interacts with the Skp1/Cdc53/F-box protein (SCF) E3 complex [16]. In budding yeast, 17 F-box proteins bind to substrate proteins degraded by the ubiquitin-proteasome system [17], and each F-box protein has a specific substrate in selecting proteins to be degraded. Overexpression of Hrt3 and of Ylr224w (Ucc1), two F-box proteins, has been shown to confer resistance to methylmercury in yeast cells [18]. In addition, yeast cells overexpressing Hrt3 and Ucc1 are not resistant to methylmercury in the presence of a proteasome inhibitor [18]. This indicates that the substrates recognized by Hrt3 or Ucc1 may include proteins that are involved in methylmercury toxicity and degraded by the proteasome. Therefore, the identification of these substrate proteins would assist in clarifying the molecular mechanism underlying methylmercury toxicity.

Yeast two-hybrid screening identified Dld3 as a substrate ubiquitinated by Hrt3 and Eno2 as a substrate ubiquitinated by Ucc1 [19]. Yeast cells overexpressing Dld3 and Eno2 exhibited higher sensitivity to methylmercury [19], indicating that Hrt3 and Ucc1 are involved in promoting proteasomal degradation by ubiquitination of Dld3 and Eno2 (Fig. 1). Dld3 is involved in the conversion of D-lactose to pyruvate [20] and Eno2 is involved in the glycolytic system [21], a metabolic pathway by which glucose is converted through several stages of reactions to pyruvate [22]. Yeast cells with overexpression of Dld3 and Eno2 showed higher sensitivity to methylmercury [19]. These suggest that an increase in the synthesis of intracellular pyruvate is one pathway of methylmercury toxicity. We previously demonstrated that the addition of nontoxic concentrations of pyruvate enhances the sensitivity of yeast and human neuroblastoma cells to methylmercury [23], suggesting that accumulation of Dld3 and Eno2, substrate proteins of the SCF complex, increases methylmercury toxicity, as does pyruvate, the metabolic product of glycolysis.

The mechanism causing pyruvate-induced methylmercury toxicity has also been examined. In yeast cells that have little pyruvate decarboxylase activity involved in the production of acetyl-CoA from pyruvate, the effect of pyruvate on methylmercury toxicity was significantly increased [23]. This result suggested that methylmercury promoted the transport of pyruvate into mitochondria and that the increased pyruvate concentrations in mitochondria were involved in intensifying the toxicity of methylmercury without being converted to acetyl-CoA. Furthermore, in human neuroblastoma cells, methylmercury treatment alone decreased the mitochondrial membrane potential, and the addition of pyruvate led to a further significant decrease. In addition, treatment with

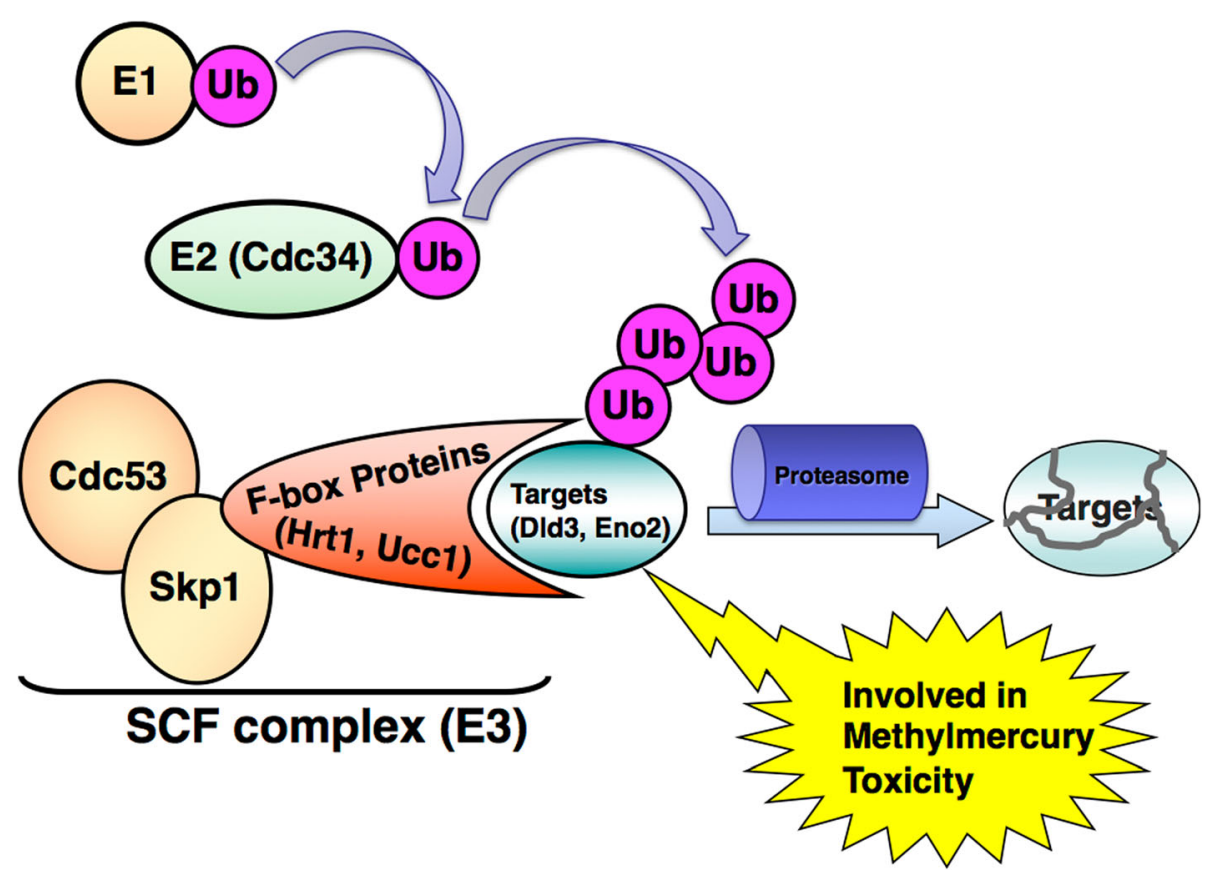

Fig. 1 The ubiquitin-proteasome system involved in methylmercury toxicity. The target proteins, Dld3 and Eno2, respectively specific to Hrt1 and Ucc1 enhance methylmercury toxicity, unless they are degraded by ubiquitin-proteasome system. E1, ubiquitin activating enzyme; E2, ubiquitin conjugating enzyme; E3, ubiquitin ligase; Ub, ubiquitin 
$\mathrm{N}$-acetylcysteine (an antioxidant) significantly alleviated the toxicity of methylmercury and significantly inhibited the intensification of methylmercury toxicity by pyruvate [23]. These data indicate that methylmercury increases mitochondrial pyruvate levels, leading to mitochondrial dysfunction and the generation of reactive oxygen species (Fig. 2).

\section{Chemokines in methylmercury toxicity}

The precise mechanism of methylmercury-induced neuronal disorders is unclear. Our research group previously found that methylmercury treatment altered the expression levels of genes in the murine cerebellum, upregulating the expression of 21 genes and downregulating that of 11 genes [24]. Increased expression was observed for several genes encoding the chemokines Ccl2, Ccl4, Ccl7, Ccl9, and Ccl12. Chemokines have been hypothesized to be involved in physiological synaptic signal transmission and developmental processes in the central nervous system [25], and their roles in methylmercury toxicity should therefore be investigated. We found that in the murine cerebrum, mRNA levels of these five chemokines increased significantly in response to methylmercury, and a similar response was observed in the kidney, with the exception of $\mathrm{Ccl} 4$ expression. No significant effect on chemokines was observed in the liver and spleen [26]. Our study of changes in chemokine gene expression in the murine cerebellum, cerebrum, kidney, liver, and spleen found that methylmercury-induced upregulation of Ccl3 and Ccl4 expression [27], implying a specificity in methylmercury toxicity to the central nervous system. We also found that methylmercury increased Ccl2 expression in human $1321 \mathrm{~N} 1$ astrocytes and elevated nuclear levels of the NF- $\mathrm{BB}$ p65 subunit; overexpression of CCL2 was inhibited by suppressing p65 expression using RNA interference [28]. More recently, we examined the transcriptional regulatory mechanism that induces Ccl4 expression in C17.2 mouse neural stem cells, and found that methylmercury stimulated the region upstream of the transcription start site and increased nuclear levels of serum response factor (SRF) and the amount bound to the Ccl4 gene promoter [29]. We also confirmed that methylmercury activated p38 and ERK, which are a part of the mitogen-activated protein kinase pathway, and these activations were involved in the induction of Ccl4 expression [29].

\section{Conclusions}

We summarized the known molecular mechanisms of methylmercury-induced neurotoxicity, including pyruvate. The findings suggest that the normal function of the ubiquitin-proteasome system in regulating pyruvatepromoting proteins may influence methylmercury toxicity. Glucose is the main energy source of the mammalian brain, and after conversion to pyruvate is used for ATP production [30]. Pyruvate accumulation in mitochondria may increase methylmercury toxicity.

Chemokines mediate inflammation in various tissues, including the brain and kidneys [31, 32]. Therefore, it is reasonable to postulate that chemokines are involved in the

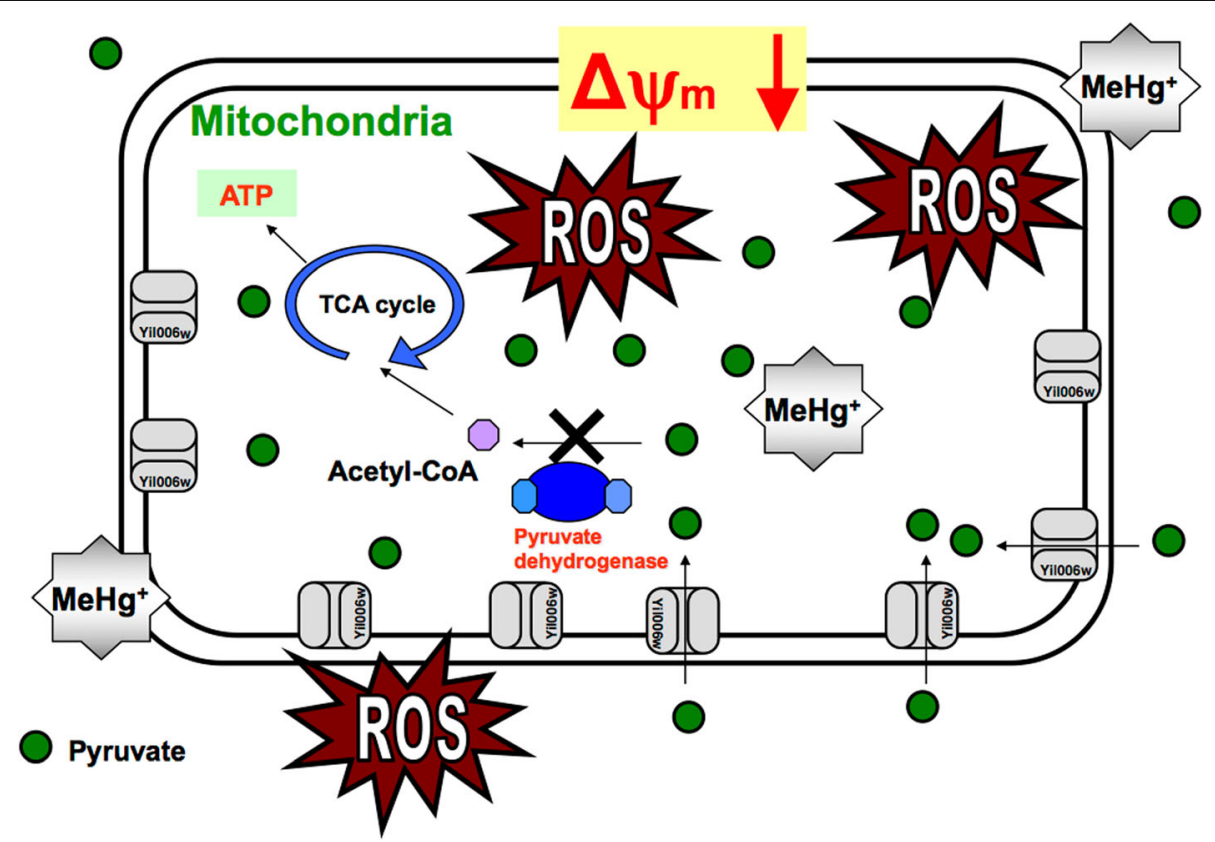

Fig. 2 The scheme of methylmercury toxic mechanism by the pyruvate transportation into mitochondria. $\mathrm{MeHg}^{+}$, methylmercury; $\Delta \psi \mathrm{m}$, mitochondrial membrane potential; ROS, reactive oxygen species 
pathway mediating methylmercury toxicity. Chemokines may function as signaling molecules in the CNS [33]. Several chemokines may be specific to methylmercury-induced disorders of the central nervous system.

Our research group recently reported several factors involved in the molecular pathways of cadmium, as well as methylmercury $[34,35]$. Such mechanistic studies in other metals may contribute to our understanding of the toxic mechanism of toxic metals. Further studies are very expected to elucidate the precise molecular mechanism of toxic heavy metals.

\section{Acknowledgements}

I am very honored to receive the Encouragement Prize of the Japanese Society for Hygiene in 2019.

\section{Authors' contributions}

J.Y.L. wrote the manuscript. G.W.H., A.N., and M.S. revised the manuscript. The author(s) read and approved the final manuscript.

\section{Funding}

This work was done without any fund.

\section{Availability of data and materials \\ Not applicable.}

\section{Ethics approval and consent to participate}

Not applicable.

\section{Consent for publication}

Not applicable.

\section{Competing interests}

The authors declare that they have no competing interests.

\section{Author details}

${ }^{1}$ Laboratory of Pharmaceutical Health Sciences, School of Pharmacy, Aichi Gakuin University, 1-100 Kusumoto-cho, Chikusa-ku, Nagoya 464-8650, Japan. ${ }^{2}$ Laboratory of Environmental and Health Sciences, Faculty of Pharmaceutical Sciences, Tohoku Medical and Pharmaceutical University, Sendai 981-8558, Japan. ${ }^{3}$ Laboratory of Molecular and Biochemical Toxicology, Graduate School of Pharmaceutical Sciences, Tohoku University, Sendai 980-8578, Japan.

Received: 2 April 2020 Accepted: 29 June 2020

Published online: 17 July 2020

\section{References}

1. Harada M. Minamata disease: methylmercury poisoning in Japan caused by environmental pollution. Crit Rev Toxicol. 1995;25:1-24. https://doi.org/10. 3109/10408449509089885.

2. Randall PM, Chattopadhyay S. Mercury contaminated sediment sites-an evaluation of remedial options. Environ Res. 2013;125:131-49. https://doi. org/10.1016/j.envres.2013.01.007.

3. Harding G, Dalziel J, Vass P. Bioaccumulation of methylmercury within the marine food web of the outer Bay of Fundy, Gulf of Maine. PLoS One. 2018; 13:e0197220. https://doi.org/10.1371/journal.pone.0197220.

4. Clarkson TW. The three modern faces of mercury. Environ Health Perspect. 2002;110(Suppl 1):11-23. https://doi.org/10.1289/ehp.02110s111.

5. Risher JF, Murray HE, Prince GR. Organic mercury compounds: human exposure and its relevance to public health. Toxicol Ind Health. 2002;18: 109-60. https://doi.org/10.1191/0748233702th1380a.

6. Clarkson TW, Magos L. The toxicology of mercury and its chemical compounds. Crit Rev Toxicol. 2006;36:609-62. https://doi.org/10.1080/ 10408440600845619

7. Cernichiari E, Brewer R, Myers GJ, Marsh DO, Lapham LW, Cox C, et al. Monitoring methylmercury during pregnancy: maternal hair predicts fetal brain exposure. Neurotoxicology. 1995;16:705-10.
8. Clarkson TW, Magos L, Myers GJ. The toxicology of mercury--current exposures and clinical manifestations. N Engl J Med. 2003;349:1731-7. https://doi.org/10.1056/NEJMra022471.

9. Clarkson TW. The toxicology of mercury. Crit Rev Clin Lab Sci. 1997;34:369-403. https://doi.org/10.3109/10408369708998098.

10. Murata K, Dakeishi M, Shimada M, Satoh H. Assessment of intrauterine methylmercury exposure affecting child development: messages from the newborn. Tohoku J Exp Med. 2007;213:187-202. https://doi.org/10.1620/ tjem.213.187.

11. Freitas AJ, Rocha JB, Wolosker $\mathrm{H}$, Souza DO. Effects of $\mathrm{Hg} 2+$ and $\mathrm{CH} 3 \mathrm{Hg}+$ on Ca2+ fluxes in rat brain microsomes. Brain Res. 1996;738:257-64. https://doi.org/10.1016/s0006-8993(96)00781-0.

12. Aschner M, Syversen T, Souza DO, Rocha JB, Farina M. Involvement of glutamate and reactive oxygen species in methylmercury neurotoxicity. Braz J Med Biol Res. 2007;40:285-91. https://doi.org/10.1590/s0100$879 \times 2007000300001$.

13. Tuite MF. Yeast models of neurodegenerative diseases. Prog Mol Biol Transl Sci. 2019;168:351-79. https://doi.org/10.1016/bs.pmbts.2019.07.001.

14. Furuchi T, Hwang GW, Naganuma A. Overexpression of the ubiquitinconjugating enzyme Cdc34 confers resistance to methylmercury in Saccharomyces cerevisiae. Mol Pharmacol. 2002;61:738-41. https://doi. org/10.1124/mol.61.4.738.

15. Hwang GW, Furuchi T, Naganuma A. A ubiquitin-proteasome system is responsible for the protection of yeast and human cells against methylmercury. FASEB J. 2002;16:709-11. https://doi.org/10.1096/fj.01-0899fje

16. Goebl MG, Yochem J, Jentsch S, McGrath JP, Varshavsky A, Byers B. The yeast cell cycle gene CDC34 encodes a ubiquitin-conjugating enzyme. Science. 1988;241:1331-5. https://doi.org/10.1126/science.2842867.

17. Skowyra D, Craig KL, Tyers M, Elledge SJ, Harper JW. F-box proteins are receptors that recruit phosphorylated substrates to the SCF ubiquitin-ligase complex. Cell. 1997;91:209-19. https://doi.org/10.1016/s0092-8674(00)80403-1.

18. Hwang $\mathrm{GW}$, Ishida $Y$, Naganuma A. Identification of F-box proteins that are involved in resistance to methylmercury in Saccharomyces cerevisiae. FEBS Lett. 2006;580:6813-8. https://doi.org/10.1016/j.febslet.2006.11.045.

19. Lee JY, Ishida Y, Kuge S, Naganuma A, Hwang GW. Identification of substrates of F-box protein involved in methylmercury toxicity in yeast cells. FEBS Lett. 2015;589:2720-5. https://doi.org/10.1016/j.febslet.2015.08.016.

20. Chelstowska A, Liu Z, Jia Y, Amberg D, Butow RA. Signalling between mitochondria and the nucleus regulates the expression of a new D-lactate dehydrogenase activity in yeast. Yeast. 1999;15:1377-91. https://doi.org/10. 1002/(sici)1097-0061(19990930)15:13<1377::Aid-yea473>3.0.Co;2-0.

21. McAlister L, Holland MJ. Targeted deletion of a yeast enolase structural gene. Identification and isolation of yeast enolase isozymes. J Biol Chem. 1982;257:7181-8.

22. Fraenkel DG. The top genes: on the distance from transcript to function in yeast glycolysis. Curr Opin Microbiol. 2003;6:198-201. https://doi.org/10. 1016/s1369-5274(03)00023-7.

23. Lee JY, Ishida Y, Takahashi T, Naganuma A, Hwang GW. Transport of pyruvate into mitochondria is involved in methylmercury toxicity. Sci Rep. 2016:6:21528. https://doi.org/10.1038/srep21528.

24. Hwang GW, Lee JY, Ryoke K, Matsuyama F, Kim JM, Takahashi T, et al. Gene expression profiling using DNA microarray analysis of the cerebellum of mice treated with methylmercury. J Toxicol Sci. 2011;36:389-91. https://doi. org/10.2131/jts.36.389.

25. Rostene W, Kitabgi P, Parsadaniantz SM. Chemokines: a new class of neuromodulator? Nat Rev Neurosci. 2007;8:895-903. https://doi.org/10.1038/ nrn2255.

26. Lee JY, Hwang GW, Kim MS, Takahashi T, Naganuma A. Methylmercury induces a brain-specific increase in chemokine CCL4 expression in mice. J Toxicol Sci. 2012;37:1279-82. https://doi.org/10.2131/jts.37.1279.

27. Kim MS, Takahashi T, Lee JY, Hwang GW, Naganuma A. Global chemokine expression in methylmercury-treated mice: methylmercury induces brainspecific expression of CCL3 and CCL4. J Toxicol Sci. 2013;38:925-9. https:// doi.org/10.2131/jts.38.925.

28. Kim MS, Takahashi T, Lee JY, Hwang GW, Naganuma A. Methylmercury induces CCL2 expression through activation of NF-kappaB in human $1321 \mathrm{~N} 1$ astrocytes. J Toxicol Sci. 2012;37:1275-8. https://doi.org/10.2131/jts.37.1275.

29. Kim M-S, Takahashi T, Lee J-Y, Toyama T, Hoshi T, Kuge S, et al. Methylmercury induces the expression of chemokine CCL4 via SRF activation in C17.2 mouse neural stem cells. Sci Rep. 2019:9:4631. https://doi.org/10.1038/s41598-019-41127-y. 
30. Mergenthaler $P$, Lindauer $U$, Dienel GA, Meisel A. Sugar for the brain: the role of glucose in physiological and pathological brain function. Trends Neurosci. 2013;36:587-97. https://doi.org/10.1016/j.tins.2013.07.001.

31. Gorter JA, van Vliet EA, Aronica E, Breit T, Rauwerda H, Lopes da Silva FH, et al. Potential new antiepileptogenic targets indicated by microarray analysis in a rat model for temporal lobe epilepsy. J Neurosci. 2006;26: 11083-110. https://doi.org/10.1523/jneurosci.2766-06.2006.

32. Shimizu H, Bolati D, Higashiyama Y, Nishijima F, Shimizu K, Niwa T. Indoxyl sulfate upregulates renal expression of MCP-1 via production of ROS and activation of NF-kappaB, p53, ERK, and JNK in proximal tubular cells. Life Sci. 2012:90:525-30. https://doi.org/10.1016/j.lfs.2012.01.013.

33. Gamo K, Kiryu-Seo S, Konishi H, Aoki S, Matsushima K, Wada K, et al. Gprotein-coupled receptor screen reveals a role for chemokine receptor CCR5 in suppressing microglial neurotoxicity. J Neurosci. 2008;28:119808. https://doi.org/10.1523/jneurosci.2920-08.2008.

34. Lee JY, Tokumoto M, Hwang GW, Lee MY, Satoh M. Identification of ARNTregulated BIRC3 as the target factor in cadmium renal toxicity. Sci Rep. 2017;7:17287. https://doi.org/10.1038/s41598-017-17494-9.

35. Sarma SN, Saleem A, Lee JY, Tokumoto M, Hwang GW, Man Chan H, et al. Effects of long-term cadmium exposure on urinary metabolite profiles in mice. J Toxicol Sci. 2018;43:89-100. https://doi.org/10.2131/jts.43.89.

\section{Publisher's Note}

Springer Nature remains neutral with regard to jurisdictional claims in published maps and institutional affiliations.

Ready to submit your research? Choose BMC and benefit from:

- fast, convenient online submission

- thorough peer review by experienced researchers in your field

- rapid publication on acceptance

- support for research data, including large and complex data types

- gold Open Access which fosters wider collaboration and increased citations

- maximum visibility for your research: over $100 \mathrm{M}$ website views per year

At $\mathrm{BMC}$, research is always in progress.

Learn more biomedcentral.com/submissions 